\title{
A sign is what? A dialogue between a semiotician and a would-be realist
}

\author{
John Deely ${ }^{1}$
}

Everyone knows that some days are better than others. I was having one of those, "other" days, when a colleague approached me to express interest in the forthcoming Annual Meeting - the 26th, as it happened — of the Semiotic Society of America.

"Come on", said the colleague. "Tell me something about this semiotics business."

"What's there to say?" I said, not in the mood for this at the moment. "Semiotics is the study of the action of signs, signs and sign systems." I knew it would not help to say that semiotics is the study of semiosis. So I let it go at that. But inwardly I cringed, for I could see the question coming like an offshore tidal wave.

"Well, what do you mean by a sign?" my colleague pressed.

Who in semiotics has not gotten this question from colleagues a hundred times? In a way it is an easy question, for "everyone knows" what a sign is. How else would they know what to look for when driving to Austin? All you have to do is play on that, and turn the conversation elsewhere.

Maybe it was a change in mood. Maybe it was the fact that I liked this particular colleague. Or maybe I wanted to play advocatus diaboli. Whatever the reason, I decided not to take the easy way out, not to play on the "common sense" understanding of sign which, useful as it is and not exactly wrong, nonetheless obscures more than it reveals, and likely as not makes the inquirer cynical (if he or she is not such already) about this "new science" of signs.

You know the routine. Someone asks you what a sign is. You respond, "You know. Anything that draws your attention to something else. Something that represents another." And they say, "You mean like a traffic sign?" And

${ }^{1}$ Presidential Address to the Semiotic Society of America delivered at the Friday, October 19, 2001, luncheon of 26th Annual Meeting held at Victoria University, Toronto, Ontario, Canada.

Author's address: John Deely, University of St. Thomas, 3800 Montrose Boulevard, Houston, Texas 77006, USA; e-mail: deelyj@stthom.edu. 
you say "Sure. Or a word. Or a billboard. Anything." And they say, "Oh. I think I get it." And life goes on.

But this time I decided to go against the grain, and to actually say what I thought a sign was. So I looked my colleague in the eye for a few moments, and finally said, not averting my gaze in the least, "OK. I'll tell you what a sign is. A sign is what every object presupposes".

My colleague's eyes widened a bit, the face took on a slightly taken-aback expression, and my ears detected an incredulous tone in the words of reply: "A sign is what?"

"What every object presupposes. Something presupposed by every object", I said again.

"What do you mean? Could you explain that?" The colleague seemed serious, and I had no pressing obligations or plans for the moment, so I said "Sure, but let's go outside." I opened my office door and indicated the stone table and bench at my disposal in the private fenced area at the end of the driveway that comes to the outer door of my office.

My colleague had no way of knowing, but in my private semiosis of that moment I could only recall the SSA Presidential Address given some seventeen years previously by Thomas A. Sebeok, wherein he compared the relations of semiotics to the idealist movement with the case of the giant rat of Sumatra, "a story for which, as Sherlock Holmes announced, the world is not yet prepared."

In that memorable speech, Sebeok had taken the occasion "to indulge in personal reminiscences, comment on the institutionalization of our common cultural concerns, and then to prognosticate about the direction toward which we may be headed." ${ }^{3}$ Now, some seventeen years later, this mantle of SSA President had fallen to me; and the institutional status of semiotics in the university world, healthy and promising as Sebeok then spoke, had in American academe become somewhat unhealthy and parlous in the succeeding years, even as the interest in and promise of the intellectual enterprise of semiotics had succeeded beyond what any of us in the 80s could have predicted in the matter of the contest as to whether the general conception of sign study should be conceived on the model of Saussurean semiology or (picking up the threads and pieces in this matter left by the teachers common to Peirce and Poinsot ${ }^{4}$ ) Peircean semiotics. ${ }^{5}$

It is true enough that I was in a position, as an associate of Sebeok's since the late $60 \mathrm{~s}$, and particularly as the only living SSA member who had

${ }^{2}$ Sebeok 1984a: 18 .

${ }^{3}$ Sebeok 1984a: 3.

${ }^{4}$ Beuchot and Deely 1995; Deely 1995.

${ }^{5}$ See Petrilli and Ponzio 2001: 4-11, esp. $6 \&$ 10. The mistaking of "a part (that is, human signs and in particular verbal signs) for the whole (that is, all possible signs, human and non-human)" that lay at the heart of this contest had already been identified as a pars pro toto fallacy and made the subject of a landmark anthology of the period: see Deely 1986; Deely, Williams, and Kruse eds. 1986. 
personally attended every Executive Board meeting since the founding of the Society in 1976 (and before that in the 1975 preparatory meeting ${ }^{6}$ ), to indulge in personal reminiscences illuminating how this passage from promising to parlous had been wrought, but the exercise would only be for my expectant colleague across the stone table hugely beside the point of anything reasonably to be expected in the present discussion. Far better, I thought, to imitate the example set by Phaedrus the Myrrhinusian in responding to Eryximachus the Physician at the symposium in the House of Agathon. The present occasion called for nothing less than a furthering of the abductive assignment that our then-elected medicine man proposed as the main mission of semiotics: to mediate between reality and illusion. ${ }^{7}$ Such was my private semiosis of the moment.

I needed no further inducement. For the public semiosis of the occasion in which I found myself I decided then and there to test the interest, intelligence, and patience of my inquiring colleague, and to plunge us together at once into the "illimitable array of concordant illusions" 8 semiotics is centrally preoccupied in bringing to light.

The first illusion under which I was sure my colleague suffered, and which every standard loose answer to the question of what a sign is serves only to further, is the impression that some things are signs while others are not - in other words, that the world of experience can be adequately divided among particulars which are signs and particulars which are not signs. Right away, the situation called for an exorcist rather than a shaman. The ghost of William of Ockham is always present at the outset of these discussions, and, not to under-rate his importance or power, at the outset, at least, it is best to exorcise him. Later on, he can be recalled to further the spirit of the discussion and, indeed, will be essential therefor; but at the outset he mostly causes trouble.

"Look around you", I urged my colleague, "and, like a good phenomenologist, give me a brief inventory of the main types of object that fall under your gaze." Of course, I had already taken into account my colleague's angle of vision, and knew that it fell directly on something that I could see only by turning, something that would be a key to the course of our conversation.

"Well", the colleague noted, "of course there is this side of the building itself whence we exited with its doors and windows; and there is the portico of the driveway with its pillars, the driveway itself, this marvellous tree which

${ }^{6}$ The First North American Semiotics Colloquium, convened July 28-30, 1975, "at the University of South Florida for the purpose of founding a Semiotic Society of America", as the jacket of the volume memorializing the colloquium (Sebeok ed. 1977) announces.

${ }^{7}$ Sebeok 1984a: 21: "the central preoccupation of semiotics, I now hold, is ... to reveal the substratal illusion underlying reality and to search for the reality that may, after all, lurk behind that illusion."

${ }^{8}$ as Sebeok put it in 1984a: 21. 
gives us shade, and this fence which gives us privacy. How did you get such a setup for your office?"

"Stick to the point", I said, "and tell me if you see for your inventory anything which could be called a sign."

"Of course. Out there, beyond the driveway and over toward the sidewalk, is the sign that identifies this building as Monaghan House."

"Yes", I said, "there is so-located a sign. But", I counseled, "you should read it more with your eyes than with your memory, my friend. Take a closer look."

"Of course", my colleague said, hand to forehead, squinting and abashed. "The sign has been changed to say 'Sullivan Hall'."

"Indeed it has", I agreed. "Are there any other signs in your inventory?"

"No", the colleague said. "From here, that is the only sign as such that appears."

"Ah so", I said, "but in your preliminary inventory you concluded by asking how I had managed such a setup for my office. So what you saw around you, even before you misidentified the sign for the building, led you to think of something not actually present in our perception here, namely, my office."

"What do you mean? Your office is right there", said the colleague, pointing to the nearest door.

"To be sure. But for that door to appear to you as 'Deely's office door' presupposes that you know about my office; and it is that knowledge, inside your very head, I dare say, that presents to you a particular door, which could in fact lead to most anything, as leading in fact to my office. So one door at least, among those you noted in this side of the building, even though you did not inventory it as a sign, nonetheless, functioned for you as a sign of my office" (the office, after all, which cannot be perceived from here, being an object which is other than the door which indeed is here perceived).

"I see what you mean", the colleague said. "So any particular thing which leads to thought of another may be called a sign."

"Perhaps", I said, "but not so fast. Tell me first what is the difference between that former Monaghan House sign and my office door, insofar as both of them function in your semiosis as representations of what is other than themselves?"

"Function in my semiosis?"

"Forgive my presumption in bringing in so novel a term. 'Semiosis' is a word Peirce was inspired to coin in the context of work connected with his Johns Hopkins logic seminar of $1883,{ }^{9}$ from his reading in particular of the 1 st century $\mathrm{BC}$ Herculanean papyrus surviving from the hand (or at least the mind) of Philodemus the Epicurean. ${ }^{10}$ Cognizant no doubt of the reliable

\footnotetext{
${ }^{9}$ Cf. Peirce (ed.) 1883.

${ }^{10}$ Philodemus i.54-40BC.
} 
scholastic adage that action is coextensive with being, ${ }^{11}$ in the sense that a being must act in order to develop or even maintain its being, with the consequent that we are able to know any being only as and insofar as we become aware of its activity, Peirce considered that we need a term to designate the activity distinctive of the sign in its proper being as sign, and for this he suggested the coinage 'semiosis'. So whenever in your own mind one thought leads to another, it is proper to speak of an action of signs, that is to say, of a function of semiosis private to you, of the way signs work, the associations that occur, if you like, in 'your particular semiosis'. In fact, the whole of your experiential life can be represented as a spiral of semiosis, wherein through the action of signs you make a guess (or 'abduction'), develop its consequences ('deduction'), and test it in interactions ('retroduction'), leading to further guesses, consequences, and tests, and so on, until your particular semiosis comes to an end. So" - and here I sketched for him on a scrap of paper a Semiotic Spiral representing our conscious life as animals. ${ }^{12}$

Now my colleague is remarkable in a number of ways, one of which is in possessing an excellent knowledge of Greek. So I was horrified but not surprised when my colleague expostulated: "Aha! An excellent coinage, this 'semiosis', though perhaps it should include an ' $\mathrm{e}$ ' between ' $\mathrm{m}$ ' and 'i'! For probably you know that the ancient Greek term for 'sign' is precisely

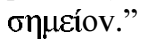

Horrified, for I had not expected to be confronted so soon with what is surely one of the most incredible tales the contemporary development of semiotics has had to tell. It was my turn to deal with the tangled web of a private semiosis, my experience in particular on learning through my assignment to team-teach a course with Umberto Eco, ${ }^{13}$ that there in fact was no term for a general notion of sign among the Greeks. I remember vividly my own incredulity on first hearing this claim. On the face of it, the claim is incredible, as any reader of translations of ancient Greek writings from the Renaissance on can testify. At the same time, the credibility of Eco as a speaker on the subject equalled or surpassed the incredibility of the claim. The evidence for the claim has since been developed considerably, ${ }^{14}$ and I

11 "Agere sequitur esse", in the original. Extended commentary in Deely 1994.

${ }^{12} \mathrm{Cf}$. Figure 1 in Sign Systems Studies 29(1): 28 - the semiotic spiral, where $A=$ abduction, $B=$ deduction, $C=$ retroduction.

${ }^{13}$ Eco and Deely 1983.

14 At the time, the main evidence in the public record (at least within the intellectual community of semioticians) traced back to 1983 , as summarized in the "Description of Contributions" for Reading 6 in Deely, Williams and Kruse 1986: xix. Since then, the substantial work of Manetti 1987 has been added from within semiotics, and the earlier independent confirmation of the original point by Markus 1972 bears consultation. A survey of the point both in its evidence in the ancient Greek context and in its more general import for the Latin Age and for the understanding of 
have been forced to deem it now more true than incredible. But how should such a conviction be briefly communicated to a colleague, particularly one more knowledgeable of Greek than I?

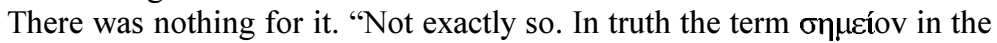
Greek age does not translate into 'sign' as that term functions in semiotics, even though the modern translations of Greek into, say, English, obscure the

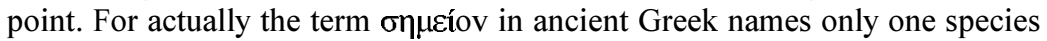
of the things we would single out today as 'signs', the species of what has been called, after Augustine, signa naturalia, natural signs." 15

Looking perplexed, my colleague avowed "I am not so sure that is true. Are you trying to tell me that the word 'sign' as semioticians commonly employ it has a direct etymology, philosophically speaking, that goes back only to the the $4^{\text {th }}$ or $5^{\text {th }}$ century AD? And to Latin, at that, rather than to Greek? To Augustine's signum rather than to the onjeíov of ancient Greece? Surely you jest?"

"The situation is worse than that", I admitted. "I am trying to tell you that the term 'sign', as it has come to signify in semiotics, strictly speaking does not refer to or designate anything of the sort that you can perceive sensibly or point out with your finger, even while saying 'There is a sign'."

Flashing me a glance in equal proportions vexed and incredulous, my colleague said: "Look. I wasn't born yesterday. We point out signs all the time, and we specifically look for them. Driving to Austin, I watch for signs that tell me I am on the right road, and what exit I should take. Surely you don't gainsay that?"

"Surely not", I sighed. "Surely not. But semioticians, following first Poinsot ${ }^{16}$ and, more recently, Peirce, ${ }^{17}$ are becoming accustomed to a hard distinction, ${ }^{18}$ that between signs in the strict or technical sense and signs loosely or commonly speaking, which are not signs but elements so related to at least two other elements that the unreflecting observer can hardly help but take them as signs among other objects which, at least comparatively speaking, are not signs. Let me explain the distinction."

"Please."

The giant rat of Sumatra was veritably on the table, a problem in a culture for which rats are not considered palatable; a problem compounded by my own situation in a subculture about as not yet prepared to entertain

semiotics today is found in Deely 2001, referred to throughout notes to this dialogue as the Four Ages.

${ }^{15}$ See the Index entries for $\boldsymbol{\sigma} \eta \boldsymbol{\mu \varepsilon i ́ o v}$ and for NATURAL SIGN in the Four Ages (Deely 2001: $838 \&$ 939).

${ }^{16}$ Poinsot 1632: Book I, Questions 1 and 3. Commentary in the Four Ages (Deely 2001: 432-33, 433n58).

${ }^{17}$ Cf. Peirce 1897 and after; commentary in the Four Ages (Deely 2001: 433n58, 639-40, 641n90.

${ }^{18}$ See the Index entry SIGN in the Four Ages (Deely 2001: 993-94), esp. the subentry "strict sense of being of sign ... distinguished from loose sense", p. 994. 
considerations of idealism as the world was in the time of Sherlock Holmes to consider the case of the very giant rat now sitting, beady-eyed, on the table between me and my colleague. Fortunately for me, or unfortunately for my colleague, it happened that the stare of those beady eyes was not fixed upon me, so it could not unnerve me so long as I kept control of my imagination.

Now you must consider, in order to appreciate the turn our conversation takes at this point, that the department in which I teach is affiliated with a Center for Thomistic Studies, and probably you know that the late modern followers of Thomas Aquinas pride themselves on "realism", a philosophical position that holds for the ability of the human mind to know things as they are in themselves, prior to or apart from any relation they may have to us. To refute idealism, these fellows generally deem it sufficient to affirm their own position, and let it go at that, their puzzlement being confined to understanding how anyone could think otherwise. ${ }^{19}$

But semiotics cannot be reduced to any such position as a traditional philosophical realism, even if Peirce be right in holding (as I think he is right $^{20}$ ) that scholastic realism is essential to if not sufficient for understanding the action of signs. In other words, the conversation had come to such a pass that, in order to enable my companion to understand why every object of experience as such presupposes the sign, I had to bring him to understand the postmodern point enunciated by Heidegger to the effect that ${ }^{21}$ "as compared with realism, idealism, no matter how contrary and untenable it may be in its results, has an advantage in principle, provided that it does not misunderstand itself as 'psychological' idealism". Best, I thought, to begin at the beginning.

"You would agree, would you not" - I put forward my initial tentative - "that we can take it as reliable knowledge that the universe is older than our earth, and our earth older than the life upon it?"

"So?" my colleague reasonably inquired.

"So we need to consider that consciousness, human consciousness in particular, is not an initial datum but one that needs to be regarded as something that emerged in time, time being understood ${ }^{22}$ simply as the measure of the motions of the interacting bodies in space that enables us to say, for example, that some fourteen billion years ago there was an initial explosion out of which came the whole of the universe as we know it, though initially bereft of life, indeed, of stars and of planets on which life could exist."

"Surely you're not just going to give me that evolution stuff? And what has that got to do with signs being something that objects presuppose, a

${ }^{19}$ See the Four Ages (Deely 2001), pp. 740-41, text and note 9.

${ }^{20}$ Peirce 1905: CP 5.423, and c.1905: CP 8.208; commentary in Deely 2001: 616628.

${ }^{21}$ Heidegger 1927: 207.

${ }^{22}$ See the re-definition of "The Boundary of Time" and "Time and Space" in the Four Ages (Deely 2001: xxix-xxxiii, 70-72). 


\section{John Deely}

proposition that doesn't exactly leap out at you as true, or even as particularly sensible?"

"Actually it is not evolution, but something more basic that I have in mind. I want to suggest that semiosis is more basic than evolution, and perhaps explains better what has heretofore been termed evolution. ${ }^{23}$ But, I admit, that is a bit much to ask at this point. Perhaps indeed I cast my net too wide. Let me trim my sails a bit, and ask you to agree only to this much: there is a difference in principle between something that exists in our awareness and something that exists whether or not we are aware of it?"

"What are you getting at?"

"A distinction between objects and things, wherein by 'object' I mean something existing as known, something existing in my awareness, and by 'thing' rather something that exists whether or not I have any awareness of it."

"But surely you do not deny that one and the same thing may be one time unknown and another time known? This is merely an accident of time, an occurrence of chance, hardly a distinction in principle."

"Ah so. But surely you do not deny that an object of experience as such necessarily involves a relation to me in experiencing it, whereas a thing in the environment of which I have no awareness lacks such a relation?"

"Well anyone can see that."

"And surely you concede that an object of experience need not be a thing in the same sense that it is an object?"

"What do you mean in saying that?"

"Consider the witches ${ }^{24}$ of Salem."

"There were no witches at Salem."

"Then what did we burn?"

"Innocent women."

"Innocent of what?"

"Of being witches."

"But the people at Salem who burned these women ${ }^{25}$ thought they were burning witches."

"They were wrong."

"So you say. But surely you see that, if the burners were wrong, something that did exist was burned because of something that did not exist? Surely you see that something public, something objective in my sense - the

${ }^{23}$ Deely 1996, in finem.

${ }^{24}$ Witches: women (usually women) who (according to the official views promulgated in medieval and renaissance church documents), in exchange for their worship, were endowed by Satan with supernatural powers. To paradigmize a huge literature: see the gloss on Kramer and Sprenger 1487 in the References.

${ }^{25}$ Actually, the witches at Salem were hung rather than burned, I am told, "death for witchcraft" being the result in either case. My colleague apparently was familiar, as I at the time, only with the more 'colorful' version of the Salem trials. 
being of a witch - was confused with something that did exist - the being of a female human organism - and that something existing was burned precisely because it was objectively identified with something that did not exist?"

"I think I am beginning to see what you are getting at", my colleague said; "but what does this have to do with signs?"

"Every mistake involves taking something that is not for something that is", I said.

"True enough", said my colleague.

"So every mistake involves an action of signs."

"Yes", said my colleague. "I see that to see a witch you have to be mistaken; but to see a woman you only need eyes, not signs. It is the truth I am interested in. By your account, all that signs account for is the possibility of being mistaken. What about the possibility of being right? Are you a realist or aren't you?"

"If you grant me that an object necessarily, whereas a thing only contingently, involves a relation to me as cognizant, then, in order to advance my argument that every object presupposes sign, I need to ask you to consider the further distinction between sensation and perception, where by the former I understand the stimulation of my nervous system by the physical surroundings and by the latter I understand the interpretation of those stimuli according to which they present to me something to be sought (+), something to be avoided (-), or something about which I am indifferent (0)."

"I see no problem with that."

"Then perhaps you will grant further that, whereas sensation so construed always and necessarily involves me in physical relations that are also objective in their termini, perception, by contrast, insofar as it assimilates sensation to itself, necessarily involves physical relations that are also objective, but further involves me in objective relations that may or may not be physical, especially insofar as I may be mistaken about what I perceive. In other words, sensations give me the raw material out of which perception constructs what are for me objects of experience, such that these objects have their being precisely as a network of relations only some of which are relations independently of the workings of my mind - and which relations are which is not something self-evident, but something that needs to be sorted out over the course of experience insofar as experience becomes human experience."

"Why do you say insofar as it becomes human experience?"

"Because, for reasons we can go into but which here I may perhaps ask you to assume for purposes of advancing the point under discussion, the notion of a difference between objects and things never occurs to any other animal except those of our own species."

"Huh?"

"Well, you're a 'realist', aren't you?"

"Of course." 


\section{John Deely}

"What do you mean by that?"

"Simple. That the objects we experience have a being independent of our experience of them."

"But you just admitted that we experience objects which are not things."

"Yeah, when we make mistakes."

"But not only when we make mistakes."

"How do you figure?"

"Is there a boundary between Texas and Oklahoma?"

"Is the Pope Catholic?"

"I take that to be a 'Yes'." I let pass that the Pope at the moment is Polish: transeat majorem.

"Of course there is a boundary between Texas and Oklahoma. I'm no Okie."

"But look at the satellite photographs. No such boundary shows up there. Would you say that the boundary exists objectively rather than physically, but nonetheless really?"

"That's a funny way of talking."

"Not as funny as thinking that social or cultural realities, whether involving error or not, exist inside your head as mere psychological states. Consider that what sensations you have depends not only on your physical surroundings but just as much upon your bodily type. Consider further that how you organize your sensations depends even more upon your biological heredity than it does upon the physical surroundings. If you see that, then you should be able to realize that the world of experience, not the physical environment as such, is what is properly called 'the objective world'; and you cannot avoid further realizing that the objective world of every species is species-specific."

"Species-specific objective worlds? I thought the objective world was the world that is the same for everybody and everything, the world of what really is."

"On the contrary, the world that is 'the same regardless of your species' is merely the physical environment, and it is, moreover, a species-specifically human hypothesis rather than anything directly perceived. Because sensation directly and necessarily puts us in contact with the surroundings in precisely something of their physical aspect of things obtaining independently of us, we can from within experience conduct experiments which enable us to distinguish within our experience between aspects of the world which exist physically as well as objectively and aspects which exist only objectively. That, my friend, is why 'realism' is a philosophical problem, not a selfevident truth. After all, 'reality' is a word, and needs to be learned like any other. You need to read something ${ }^{26}$ of Peirce."

${ }^{26} \mathrm{I}$ had in mind the modern distinction between primary and secondary qualities of sensation, and the very different ways in which the scholastic realists of Latin times and Peirce at the end of modern times himself resolved the distinction to the common 
"You seem to be veering into idealism." My colleague frowned mightily, hardly in sign of approval.

"Not at all. I thought you liked to acknowledge what is? And certainly an objective world shot through with emotions and the possibilities of error, which is specific to humans and even subspecific to different populations of humans is the reality we experience, not just some physical environment indifferent to our feelings about it? The indifferent physical environment is a hypothetical construct, a well-founded guess, which science confirms in some particulars and disproves in others. For surely you don't think it was science or philosophy that disproved witches, do you? Haven't you read the old papal decrees on the subject, or the theological treatises on how to discriminate between ordinary women and women who are witches? $?^{27}$ It behooves you to do so if you are married or even have a girlfriend."

"But all you are talking about is mistakes we have made, psychological states disconnected from objectivity."

"On the contrary, there are no such thing as psychological states disconnected from objectivity. Objectivity precisely depends upon psychological states which give the subjective foundation or ground for the relations which terminate in the publically experienced interpretations that are precisely what we call objects. The key to the whole thing is relation in its unique being as irreducible to its subjective source always terminating at something over and above the being in which the relation is grounded." I could not help but think of the two main texts in Poinsot ${ }^{28}$ which had so long ago first directed my attention to this simple point made quasi-occult over the course of philosophy's history by the obtuse discussions of relation after Aristotle. ${ }^{29}$

"But I thought knowledge consisted in our assimilation of the form of things without their matter."

Now I knew for sure my colleague was indeed a closet Thomist at least, versed in the more common Neothomist version of ideogenesis, or theory of the formation of ideas through a process of abstraction.

"Well", I ventured, "in the first place, that is not a self-evident proposition, but one highly specific medieval theory of the process of abstraction; and further, absent the context of a full-blown theory of relations as

end of vindicating the transcendental equivalence of truth with being - that "communication and being coincide", as Petrilli and Ponzio (2001: 54) put it. See the Index entries QUALITIES GIVEN IN SENSATION, and TRANSCENDENTALS, in the Four Ages (Deely 2001: 973, 1005-6).

${ }^{27}$ See Kramer and Sprenger 1486.

${ }^{28}$ Poinsot 1632: Treatise on Signs, Second Preamble, Article 2, 93/17-96/36; and Book I, Question 1, 117/18-118/18.

${ }^{29}$ See the summaries of the matter essayed by Grote 1872, as learned as the confusion gets. Cf. the discussion in the Four Ages (Deely 2001), pp. 72-78, 226-231, and $423-427$. 
suprasubjective links ${ }^{30}$ to what is objectively other than ourselves with all our psychological states, affective as well as cognitive, such a theory is finally incoherent. For any 'form', with or without 'matter', if and insofar as it is 'in me', is part and parcel of my subjectivity, except and insofar as it mayhap give rise to a relation to something over and above my subjectivity, which is by definition what is meant by 'terminating objectively'."

"Could you state clearly your meaning of 'subjectivity' here", asked my colleague.

"Indeed. Subjectivity is the sum total of everything that distinguishes me from the rest of the universe, ${ }^{31}$ and relations are whatever ties over and above my subjectivity link me to anything other than myself, be that other physical as well as objective or merely objective."

"Merely objective?" my colleague queried with eyebrows raised.

"Merely objective: existing as known and insofar publically accessible but not as such existing physically in the environment ${ }^{32}$, like the border of Texas with Mexico or the office of President of the United States, and so on. Subjective existence is physical existence, including the whole of one's private psychological states. Objective existence, by contrast, is public in principle, in the way that any two otherwise isolated subjectivities can yet be in relation to a common third."

"But this 'common third', as you put it, surely must be something real?"

"Not at all, if by 'real' you mean existing independently of the workings of mind, something subjective, a physical entity. It suffices that it 'exist' as the terminus opposed to the foundation or ground in subjectivity of some relation, which relation as a relation exceeds the subjectivity in which it is grounded by terminating at something over and above subjectivity as such, something 'other' than that subjectivity. This 'other' may indeed also exist independently of the cognitive or affective relation terminating thereat, in which case it will be a thing as well as an object. Subjectivity, you can see, is what defines things as things. Objectivity, by contrast, obtains only in and through relations, normally a whole network of relations, which give even the things of the physical environment their status as experienced and whatever meaning they have for the lifeform experiencing them. Since objectivity always includes (through sensation) something of the subjectivity of things in the environment, this objective meaning is normally never wholly divorced from the subjective reality of the physical world, but it is never reducible to that reality either."

${ }^{30}$ See the Index entries for SIGN and SUPRASUBJECTIVDE BEING in the Four Ages (Deely 2001: 993-94, 1001-2).

${ }^{31}$ See the Index entry SUBJECTIVE BEING, SUBJECTIVITy in the Four Ages (Deely 2001: 1000-1001), in contrast with the entry for INTERSUBJECTIVE BEING, INTERSUBJECTIVITY.

${ }^{32}$ See the Index entry OBJECT, OBJECTIVE BEING in the Four Ages (Deely 2001: 944-45). 
"Surely you are not saying that every object is merely the terminus of some relation?"

'Exactly so - some relation or complex of relations, a 'semiotic web', as we like to say in semiotics. Except your use of 'merely' here seems hardly appropriate, when one considers that the terminus of cognitive and affective relations normally involves something of the subjectivity of things in their aspects as known, even though the terminus of every relation as terminus owes its being as correlate to the fundament to the suprasubjectivity distinctive of the being peculiar to and definitive of relation."

"And where does sign come in?"

"At the foundation, my friend; but not as the foundation. That was the mistake the scholastics made ${ }^{33}$ in trying to divide signs into 'formal' and 'instrumental' signs without realizing that our psychological states are no less particulars than are physical objects we point to when we single something out as a 'sign'."

"You are losing me."

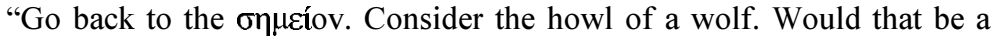

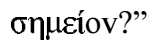

My colleague pondered, consulting within the privacy of self-semiosis a knowledge of ancient Greek. I awaited the result of this consultation.

"I am not so sure. The on $\mu \varepsilon i ́ \alpha$ were always sensible events, to be sure, and ones deemed natural at that. But they were primarily associated, as I remember, with divination, wherein the natural event manifested a will of the gods or a destined fate, or with medicine, wherein the natural event is a symptom enabling prognosis or diagnosis of health or sickness. No, I am not so sure the howl of a wolf would fall under $\sigma \eta \mu \varepsilon i ́ o v$, or at least I don't see how it would."

"All right then", I suggested, "let us consider the howl of a wolf first just as a physical event in the environment, a sound or set of vibrations of a certain wavelength propagating over a finite distance from its source within the physical surroundings."

"I see no difficulty in that", my colleague allowed agreeably.

"Now let us suppose two organisms endowed with appropriate organs of what we call hearing, situated within the range of propagation of that sound. What would you suppose?"

"I would suppose they would hear the sound, if they are not asleep or too distracted."

"Let us suppose they hear the sound, the one organism being a sheep and the other another wolf. Now the sound occurring physically and subjectively in the environment independently of our organisms' hearing of it enters into a relation with each of the two organisms. The sound not only exists physically, it now exists also objectively, for it is heard, it is something of which the organisms are respectively aware. It is a kind of object, but what kind? For

${ }^{33}$ See Chapter 8 of the Four Ages (Deely 2001: esp. 388-391) 
the sheep it is an object of repulsion (-), something inspiring fear and an urge to hide or flee. For the other wolf, a male wolf, it happens - heeding the advice of St. Thomas to use sexual examples to make something memorable - let us say that the howl reveals a female in heat. Such a sound, no different in its physical subjectivity from the vibrations reaching the frightened sheep, inspires in the male an attraction, as it were $(+)$, what former President Carter might call 'lust in the heart'."

"What are you saying?"

"That one and the same thing occurring in the environment gives rise in awareness to quite different objects for different organisms, depending on their biological types. Sensations become incorporated into perceptions of objects not merely according to what things are in the surroundings but especially according to how the sensations are interrelated within the experience of the perceiving animal as part of its total objective world."

"So this is what you meant when you said that objective worlds are species-specific?"

"Exactly so. Every organism in its body is one subjectivity among others, a thing interacting physically with other things in the environment. But if the organism is a cognitive organism, its body has specialized parts suited to a psychological as well as a physiological response to those physical environmental aspects proportioned to the organ of sense. The psychological response in those cases is no less 'subjective', no less 'inside the organism', than the physical effects of the interaction; but the psychological effect gives rise to a cognitive relation, a relation of awareness of something in the environment. But what is that 'something'? The organism, according to its own nature and past experiences, attaches a value to the stimulus and relates that stimulus to its own needs and desires. In other words, the mere stimulus of sensation becomes incorporated objectively into a whole network of experience wherein it acquires a meaning."

"But that is subjectivism", my colleague blustered indignantly. "Values are real, objective, not subjective. You are making them subjective."

"Pay attention", I pleaded. "Of course the values are objective. Anything existing within awareness is objective. They are also bound up with the subjectivity of the physical environment, both in the being proper to whatever is the source of the stimulus and in the being of the cognizing organism. Insofar as the subjectivity of the physical world bespeaks a being independently of whatever I may know, feel, or believe, the values partake of that being. But, as values, they reveal more the being of the organism evaluating than the subjective nature of the stimulus in the environment. They belong as values to the species-specific objective world of the experiencing organism."

"This is troubling", my colleague alleged.

"Let me put you at ease", I offered. "In order for an organism to be aware of something outside itself, there must be inside itself a disposition or state on 
the basis of which it is related cognitively (and, I would add, affectively ${ }^{34}$ ) to that outside other. If the outside other has an existence of its own quite independent of the cognition of the cognizing organism, then it is a thing, indeed. But insofar as it becomes known it is an object, the terminus of a relation founded upon the psychological states inside the organism. Neither the relation nor the thing become object are inside the knower. All that is inside the knower is the disposition or state presupposed for the thing to exist as known. ${ }^{35}$ And the relation is inside neither the knower nor the known but is over and above both of them. Compared to the subjectivity of either the knower or the known the relation as such is suprasubjective. But as related cognitively to the knower the thing known is the terminus of a relation founded in the knower's own subjectivity. As terminating the relation it is an object. That same object if and insofar as it has a subjective being of its own is not merely an object but also a thing."

"But what if the object has no subjectivity proper to it?" my colleague probed, thinking, as I suspected from his nonverbal signs, of Salem and witches.

"Then it is only an object, what the scholastic realists used to call a 'minddependent being, ${ }^{36}$ So do pay attention: every mind-dependent being is an objective reality or being, but not every objective reality is a mind-dependent being. Some objects are also things, in which case they are mind-independent beings ${ }^{37}$ as well as objective realities."

"But I thought an ens rationis, what you call a mind-dependent being, was a mere mental reality, a psychological state like error or delusion."

"Hardly. Surely you recall that, according to the scholastic realists so beloved of Peirce, logical entities all are entia rationis? And the relations of logic are supremely public, binding upon all? Now it is true that logic reveals to us only the consequences of our beliefs, of our thinking that things are this way or that, not necessarily how things are in their independent being. But the fact that logical relations are public realities, not private ones, that logical relations reveal inescapable consequences of this or that belief, not private whims, already tells you that they belong to the Umwelt, not to the Innenwelt, and to the Umwelt as species-specifically human at that."

"Umwelt? Innenwelt? Where does that come from?"

"Sorry. Umwelt is shorthand for objective world. In the case of the species-specifically human objective world it is often called rather a Lebenswelt; but please", I pleaded, "let us not get into that particular right now or we will never get to the bottom of the question you have raised as to

${ }^{34}$ See the discussion below of "cathexis" and "cathecting": p. 28, n. 63; and p. 32 , n 82.

${ }^{35}$ See the Index entry FORMAL SIGN in the Four Ages (Deely 2001: 893-894).

${ }^{36}$ Ens rationis. See the Index entries ENS RATIONIS and MIND-DEPENDENT BEING in the Four Ages (Deely 2001: 883-884 and 934-935, respectively).

37 Entia realia. See the Index entries ENS REALE and MIND-INDEPENDENT OR PHYSICAL in the Four Ages (Deely 2001: 884-885 and 935-937, respectively). 
why a sign is best defined at this stage of history as what every object presupposes."

"But", my colleague interjected, "why in the world do you speak of the definition we are seeking to plumb as best 'at this stage of history'? Surely you know that a real definition tells what something is, and is not subject to time? Are species not eternal?"

"Surely you will allow for more subtlety than that as regards definitions?" I replied hopefully. "After all, even when we try to express in words what a thing is, it is our understanding of the thing that we express, not purely and simply the thing itself? And this is true even when and to the extent that our understanding actually has some overlap, identity, or coincidence with the being of the thing - even when, that is to say, our definition partially expresses a thing objectified, a thing made object or known?"

"I see what you mean. Even a definition supposed real expresses only our best understanding of some aspect of real being, and insofar as this understanding is not exhaustive it may admit of revision or of being supplanted through subsequent advances or alterations of understanding", my colleague allowed.

"I am glad you see that", I breathed aloud, "for, in the case of the sign, there have been at least three, or even more (depending on how you parse the history) revisions of the definitory formula generally accepted, ${ }^{38}$ and I expect more to come."

"Don't discourage me", my colleague pleaded. "Let us at least get clear for now about this new formula you deem best at 'our present historical moment'. I get your meaning of Umwelt. What about this Innenwelt business?"

"Innenwelt is merely shorthand for the complexus of psychological powers and states whereby an organism represents to itself or 'models' the environment insofar as it experiences the world. So Innenwelt is the subjective or private counterpart to the objective world of public experience comprising for any species its Umwelt."

"That helps, but I fail to see what all this new terminology and idiosyncratic way of looking at things has to do with signs, let alone with signs being presupposed to objects."

"Then let me introduce at this point the great discovery of semiotics, actually first made in the 16th century, or early in the 17 th at the latest, ${ }^{39}$ although never fully marked terminologically until Peirce resumed the Latin discussion around the dawn of the 20 th century. ${ }^{40}$ Signs are not particular things of any kind but strictly and essentially relations of a certain kind, specifically, relations irreducibly triadic in character."

\footnotetext{
${ }^{38}$ See the Index entry for DEFINITION OF SIGN in the Four Ages (Deely 2001: 874875).

${ }^{39}$ See the Conimbricenses 1607, especially in the bilingual edition by Doyle 2001 .

${ }^{40}$ See the Index entry INTERPRETANT in the Four Ages (Deely 2001: 914-915).
} 
"But surely you are not denying that that", my colleague said, pointing to the physical structure renaming the building beside us as Sullivan rather than Monaghan, "is a sign?"

"No, I am not exactly denying that; what I am denying is that what makes what you are pointing to a sign is anything about it that you can point to and directly see with your eyes or touch with your hands. What makes it a sign is that, within your Umwelt, it stands for something other than itself; and because it succeeds (in your Umwelt) in so standing it is for you a sign. But what makes it thus succeed is the position it occupies in a triadic relation; and, strictly speaking, it is that relation as a whole that is the being of sign, not any one element, subjective or objective, within the relation."

"I don't understand", the colleague confessed. But there was interest in the voice, not impatience or indifference. So I was encouraged to continue.

"I suppose we usually think of a relationship dyadically, as a link between two things", I ventured.

"Sure", my colleague interjected, "like the relation between a sign and what it signifies. Why don't you just accept Jakobson's famous formula for defining sign, ${ }^{41}$ aliquid stat pro aliquo, one thing standing for another?"

"I am delighted you are familiar with that essay by Jakobson, which has become a classic, ${ }^{42}$ one of the landmarks in the semiotic development of the last century", I said, pleasantly surprised again by my colleague's learning. "It took me almost nineteen years to realize a major flaw in that formula, in that the aliquo allows for a misunderstanding along Cartesian lines, wherein objects are reduced to ideas in the subjective or psychological sense. I made a major address to the Semiotic Society of America on this point in 1993, ${ }^{43}$ showing, or attempting to show, that this classic formula should be revised to read rather aliquid stat pro alio, in order to leave no doubt that the sign, unlike an object, ${ }^{44}$ stands never for itself but always for another than itself."

"But since you have brought up Jakobson's formula", I continued, "let me remind you that he intended the formula to express the relation distinctive or constitutive of sign, a relation Jakobson felicitously characterized as renvoi."

"I had forgotten that expression renvoi", my colleague admitted, "but I don't see how it helps us here."

"Well", I said, "I am slow, proof of humanity. Since my initial proposal for revision of Jakobson's formula eight more years have passed before a second revision occurred to me as necessary."

"A second revision?" queried my colleague.

"Yes. If you will recall, renvoi for Jakobson was not merely the relation of sign to signified, insofar dyadic, as you have suggested. Renvoi was a

${ }^{41}$ Jakobson 1979.

${ }^{42}$ See Eco 1987.

${ }^{43}$ Deely 1993, the SSA Thomas A. Sebeok Fellowship Inaugural Lecture.

${ }^{44}$ Poinsot 1632: Tractatus de Signis, Book I, Question 1, 116/14-117/17; Deely 1986a. 
relationship wherein the so-called sign manifested its significate to or for someone or something. So the formula in fact not only needs to be so revised as to preclude the typically modern epistemological paradigm wherein signs as other-representations can be confused with objects as self-representations, as I manifested in my 1993 Sebeok Fellowship inaugural address, it needs also to be revised to include a Latin dative expressing the indirect reference to the effect wherein an action of signs achieves it distinctive outcome."

"You raise two questions in my mind", my colleague said with some agitation. "You say that the sign manifests 'to or for someone or something'. How is 'to' equivalent with 'for'? And how is 'someone' equivalent with 'something'? But before you respond to these two queries, please," my colleague requested, "tell me how would you have the classic formula finally read."

"Aliquid alicuique stans pro alio, one thing representing another than itself to yet another", I suggested, "although the impersonal verb form stat would work as well as the participial stans. Only with a final revision like this could it be said finally, as Sebeok said (as I now see) a little prematurely, ${ }^{45}$ that by the term renvoi Jakobson had 'deftly captured and transfixed each and every sign process conforming to the classic formula'; for if a relation is not triadic, it is not a sign relation. Whence the truly classic formula: Aliquid stat alicuique pro alio."

"Very interesting", my colleague allowed. "Now could you answer my two questions?"

"Your questions cut to the heart of the matter. Consider the bone of a dinosaur, which is known as such. It functions in the awareness of the paleontologist as a sign. He recognizes it, let us say, as the bone of an Apatosaurus. Consider that same bone chanced upon by a Roman soldier in the last century BC. Whatever it signified, if anything, to the soldier, it did not signify an Apatosaurus. Agreed?"

"Agreed", my colleague allowed. "In those circumstances it was more an object than a sign, not a fossil at all, so to speak."

"And yet it was a fossil, waiting to be seen through the right eyes. It was not an Apatosaurus sign to someone there and then, in that last century, but it remained that it was prospectively such a sign for a future observer."

"Yes", the colleague conceded, "but that prospective signification was to someone, not to something."

"You raise the difficult question of whether the 'to or for which' of a sign need always be a cognitive organism or not. Let me acknowledge the difficulty of the question, but not try to answer it now. Suffice it to say, for the moment at least, that when an organism interprets something as a sign, that interpretation is required to complete the sign's signification as something actual here and now."

\footnotetext{
${ }^{45}$ Sebeok 1984: 9.
} 
"I can see that. A sign requires an interpretation if it is to succeed as a sign and not just be some dumb object. But I don't see how an inorganic substance can provide an interpretation. Come on!"

"So", I continued, proposing to steer the discussion more directly to the point at hand, "pay attention: what you call a sign, which I will shortly manifest is a loose rather than a strict way of speaking, doesn't just (dyadically) relate to what it signifies, it signifies what it signifies (triadically) to or for something else. Always hidden in the sign-signified dyad is a third element, the reason why or ground upon which the 'sign', as you call it, signifies whatever it does signify and not something else." I didn't not see the point, unless my colleague fastened upon it, which happily did not happen, in pointing out here the important distinction between "ground" in the technical Peircean sense redolent of the old objectum formale of scholastic realism and "ground" in the scholastic realist sense of fundamentum relationis. ${ }^{46}$ Instead, my colleague called for a concrete illustration, much simpler to provide. I secretly breathed a sigh of relief.

"Give me an example", demanded the colleague.

I hastened to comply, before the absolute point so pertinent here might occur to my interlocutor (inexplicably, my friend Joe Pentony came into my mind).

"I make a noise: 'elephant'. It is not just a noise, but a word. Why, hearing the noise 'elephant' do you not think of a thin-legged, long-necked, brown-spotted animal that nibbles leaves instead of a thick-legged, large gray animal with a prehensile proboscis?" Since my colleague fancied to be a 'realist', it was not difficult to anticipate the reply about to come. Nor was I disappointed.

"Obviously because 'elephant' means elephant and not giraffe", the colleague said, this time a touch impatiently.

"Yes, of course", I granted, "but is that not only because of the habit structures internalized in your Innenwelt which make the noise 'elephant' a linguistic element in our Lebenswelt on the basis of which we are habituated to think first, on hearing the noise, of one particular animal rather than another? So in the experience of any signification is there not only the 'sign' loosely so-called and the signified object, but also the matter of the basis upon which the sign signifies this object rather than or before some other object? You see that?"

"I do."

"Then you see that the relation making what you with your finger point out as a 'sign' to be a sign is nothing intrinsic to the so-called sign, but rather something over and above that subjective structure; to wit, a relationship, which has not one term but two terms, to wit, the signified object for one and,

${ }^{46}$ See the Index entry for GROUND, senses A \& B, in the Four Ages (Deely 2001: 900-903). 


\section{John Deely}

for the other, the reason why that rather than some other is the object signified?"

"I think I do see that. I think. But please explain further, so I can be sure." Realists like to be 'sure'. Infallibility is their ideal goal, as it were, the modern variety at least (rather more naive in this than their Latin scholastic forebears, I might add), ironically the final heirs of Descartes, who prized certainty, in the end, above 'realism'.

"Well, here, history can be a great help. Animals, including human animals, begin with an experience of objects, and objects normally given as outside of or other than themselves. In order to mature and survive, every animal has to form an interior map, an Innenwelt, which enables it sufficiently to navigate its surroundings to find food, shelter, etc. This 'sufficiently' is what we call an Umwelt, and it contrasts in principle with, even though it partially includes something of, the things of the physical environment."

"I think", my colleague marvelled, "I begin to understand your ironic manner whenever the subject of 'realism' in philosophy arises. Realists assume our experience begins with things as such, whereas now I see that our experience directly is only of things as subsumed within objects and the species-specific structure of an objective world! If entia realia and entia rationis are equally objective within our experience, then the sorting out of which-is-which is a problem rather than a given!"

"Exactly so", I answered, delighted at this sudden burst of light from my colleague. "Now if only I can get you to see how object presupposes sign, perhaps we can get some lunch."

"Please do so", the colleague said, "and, now that you mention it, the quicker the better, for I am getting hungry."

"Permit me an obiter dictum, nonetheless", I pleaded, "for I think it will facilitate our progress to a successful outcome of the main point before us."

"By all means", the colleague allowed, drawing an apple from a bag and taking a bite.

"Even though you have heretofore deemed yourself a 'realist'," I ventured, "I have noticed from earlier conversations that you have a definite partiality to phenomenology, even though Husserl himself conceded that his position in the end proved but one more variant in the characteristically modern development of philosophy as idealism. ${ }^{47}$

"So notice two points. First, the phenomenological idea of the 'intentionality' of consciousness ${ }^{48}$ reduces, within semiotics, to the theory of relations, ${ }^{49}$ and expresses nothing more than the distinctive characteristic of psychological states of subjectivity whereby they give rise necessarily to

\footnotetext{
${ }^{47}$ See Husserl 1929; Spiegelberg 1965: I, 155.

48 From Brentano 1874. Brief notice in the Four Ages (Deely 2001: 404 and 561n38); extended comment in Deely 1978.

${ }^{49}$ Deely 1971, 1975, 1978.
} 
relations triadic rather than dyadic in character. But second, and more fundamentally, recall the question with which (among others) Heidegger concluded his original publication of Being and Time: $:^{50}$

Why does Being get 'conceived' 'proximally' in terms of the present-at-hand and not in terms of the ready-to-hand, which indeed lies closer to us? Why does this reifying always keep coming back to exercise its dominion?

Within semiotics we can now give an answer to this question."

"We can?"

"Indeed. Ready-to-hand is the manner in which objects exist within an animal Umwelt. Human beings are animals first of all, but they have one species-specifically distinct feature of their Innenwelt or modeling system, a feature which was first brought to light in the postmodern context of semiotics, so far as I know, by Professor Sebeok, ${ }^{51}$ namely, the ability to model objects as things. That is to say, the human modeling system or Innenwelt includes the ability to undertake the discrimination within objects of the difference between what of the objects belongs to the order of physical subjectivity $^{52}$ and what belongs wholly to the order of objects simply as terminating our awareness of them. ${ }^{53}$ Perhaps you recall from your reading of Thomas Aquinas that he identified the origin of human experience in an awareness of being prior to the discrimination of the difference between ens reale and ens rationis?"

"Actually I don't recall any such discussion in St. Thomas."

"Fair enough, and we don't want to get completely off the track. Later on you might want to look up the point in Aquinas and give some consideration to its implications; for it seems to me that what he is saying is that our original experience includes something of the world of things but definitively cannot be reduced to the order of ens reale. Comparative realities and unrealities alike are discovered from within, not prior to, objectivity. ${ }^{54}$ The experience of that contrast, indeed, is what transforms the generically animal Umwelt into a species-specifically human Lebenswelt ${ }^{55}$ wherein even witches can be mistaken for realities of a definite type, and wherein it may be hard to realize that the mind-independent revolution of the earth around the sun is not

${ }^{50}$ Heidegger 1927: 437.

${ }^{51}$ See, inter alia, Sebeok 1984.

${ }^{52}$ Entia realia.

${ }^{53}$ Entia rationis.

${ }^{54}$ In the Four Ages (Deely 2001), see the whole of Chapter 7, but esp. pp. 341357, and the Table on p. 354.

${ }_{55}$ This term is from Husserl 1936 in particular; in Aquinas's own manner of speaking, he calls the focus or "starting point" of species-specifically human awareness ens primum cognitum, which then subdivides over the course of experience into ens reale and ens rationis. See the Four Ages (Deely 2001), Chap. 7. 
unreal whereas the mind-dependent revolution of the sun around the earth is not real."

"What about Heidegger's objective distinction between the ready-to-hand and the present-at-hand?", my colleague pressed.

"Simple. This is a distinction that does not arise for any animal except an animal with a modeling system capable of representing objects (as such necessarily related to us) according to a being or features not necessarily related to us but obtaining subjectively in the objects themselves (mistakenly or not, according to the particular case) - an animal, in short, capable of wondering about things-in-themselves and conducting itself accordingly. Now, since a modeling system so capacitated is, according to Sebeok, what is meant by language in the root sense, whereas the exaptation of such a modeling in action gives rise not to language but to linguistic communication, ${ }^{56}$ and since 'language' in this derivative sense of linguistic communication is the species-specifically distinctive and dominant modality of communication among humans, we have a difficulty inverse to that of the nonlinguistic animals, although we, unlike they, can overcome the difficulty."

"And what difficulty is that?"

"Within an Umwelt, objects are reality so far as the organism is concerned. But without language, the animals have no way to go beyond the objective world as such to inquire into the physical environment in its difference from the objective world. Within a Lebenswelt, by contrast, that is to say, within an Umwelt internally transformed by language, the reality so far as the organism is concerned is confused with and mistaken for the world of things. Objects appear not as mixtures of entia rationis with entia realia, but simply as 'what is', 'real being', 'a world of things'."

"That is the general assertion of 'realists", my colleague mused. "It also reminds me of Reid's 'philosophy of common sense'."

"As well it might", I said. "Descartes and Locke confused objects as suprasubjectively terminating relations with their counterposed subjective foundations or bases in the cognitive aspect of subjectivity, thereby reducing Umwelt to Innenwelt; Reid, in seeking to counter them and, especially, Hume after them, confused public objects with things, ens primum cognitum with ens reale (in the earlier terms of Aquinas), thereby reducing Umwelt to physical environment. But the physical universe of things is distinguished from within the world of objects as the sense of that dimension of objective experience which reveals roots in objects that do not reduce to our experience of the objects. Reality in this hard-core sense of something existing independently of our beliefs, opinions, and feelings is not 'given' to some magical faculty of 'common sense'. There is no 'gift of heaven' facilely discriminating 'the real' for our otherwise animal minds - a gift such as

${ }^{56}$ This distinction, taken from Sebeok, is one of the bases upon which the history of philosophy as a whole needs to be rewritten: see the Four Ages, Chapter 1.

${ }^{57}$ See "What to do with common sense?" in the Four Ages (Deely 2001: 547-48). 
Reid avers ${ }^{58}$ which only bias or 'some mistaken religious principle' can mislead."

"So you are saying that the reality of objects within experience, for any animal, is a confused mixture of entia realia and entia rationis, but that this confusion only comes to light in the experience of human animals by means of a species-specific modeling of the world which you call language?"

"That is what I am saying."

"Well, it makes sense, I think; but it is a strange way of speaking. I need to digest this a bit before I can decide where to agree and where to differ. Enough of your obiter dictum. I want to get to the bottom of this objects presupposing signs business, and get some lunch."

"Back, then, to history", I urged. "You can see right off that every animal will use what it senses perceptually to orientate itself in the environment. Among these elements sensed some therefore will come to stand for something other than themselves. The most impressive of such sensory elements would be those manifesting the powers that hold sway over human existence, nature, on the one hand, and gods, on the other. So in the ancient

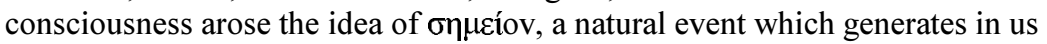
the expectation of something else, an element of divination in the case of the gods, a symptom in the case of medicine. ${ }^{59}$ This idea permeates the ancient Greek writings. But, at the beginning of the Latin Age, Augustine unwittingly introduces a radical variant upon the ancient notion. I say 'unwittingly', not at all to disparage Augustine, but to mark the fact important in this connection that his ignorance of Greek prevented him from realizing what was novel about his proposal, and how much it stood in need of some explanation regarding its possibility.

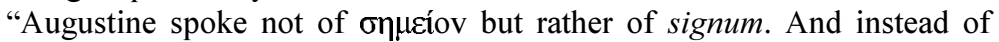
conceiving of it as a natural sensory occurrence or event, he conceived of it simply as a sensible event whether natural or artificial. At a stroke, by putting the word 'natural' under erasure, Augustine introduced the idea of sign as general mode of being overcoming or transcending the division between nature and culture. Specifically (and incredibly ${ }^{60}$ ), for the first time and ever after, human language (more precisely, the elements and modalities of linguistic communication) and culture generally came to be regarded as a system of signs (signa ad placita) interwoven with the signs of nature, the

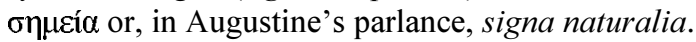

"To a man the Latins followed Augustine in this way of viewing the sign. But, gradually, problems came to light. In particular, at least by the time of

${ }^{58}$ Reid 1785: 604-5. A useful — if still presemiotic — discussion of "Thomas Reid and the Signs of the Times" is essayed in McInerny 2001: 52-56.

${ }^{59}$ See Sebeok 1984 b on the latter point, Manetti 1987 on the former.

${ }^{60}$ See the discussion of Markus 1972 in the Four Ages (Deely 2001: 218-20, and esp. 406n95). 
Aquinas, if not a century earlier in Abaelard, ${ }^{61}$ question arose as to which is the primary element in the being of sign: being sensible, or being in relation to another? For, the Latins noticed, all of our psychological states, the passiones animae, put us into a relation to what they themselves are not, and present this 'other' objectively in experience. ${ }^{62}$ Is not this relation of one thing presenting another than itself in fact more fundamental to being a sign than being a sensible element, whether natural or cultural? And if so, should not the passions of the soul, which, as effects of things necessarily provenate relations to what is objectively experienced, be regarded veritably as signs, even though they are not themselves directly sensible or, indeed, even outside of ourselves, outside of our subjectivity?

"So at another stroke was overcome the distinction between inner and outer as regards the means of signification, a landmark event paralleling Augustine's overcoming of the divide between nature and culture. The states of subjectivity whereby we cathect ${ }^{63}$ and cognize objects, the scholastics proposed, are themselves a type of sign, even though we do not access them by external sensation. Call them 'formal signs', they proposed, in contrast to

${ }^{61}$ See "The So-Called Dark Ages", Chapter 6 of the Four Ages (Deely 2001: esp. 243-247).

${ }^{62}$ See the Index entries PASSIONS OF THE SOUL and FORMAL SIGN in the Four Ages (Deely 2001: 950 and 893-94, respectively).

${ }^{63}$ Though my interlocutor raised no question about this term, and later in our discussion (see p. 32 toward bottom, below) manifested a thorough mastery of its usage as pertaining to semiotics, nevertheless, the term is important to the future of semiotics and sufficiently unfamiliar to most readers at the time this transcript was made to warrant a note of explication. An organism responds to an object not only by cognizing it but, at the same time, by cathecting that object as desirable, undesirable, or 'neutral', as we have said. The former relation arises from the cognitive representations (or 'ideas'), the latter from the emotional representations (or 'feelings') accompanying or evoked by the ideas. Thus cognition and cathexis are twin processes within zoö- and anthropo-semiosis, "simultaneously given and only analytically separable", as Parsons, Shils, and Olds best noted (1951: 68-69; see also their 1951a: 110).

The centrality of this idea for semiotics, particularly as regards the concept of Umwelt, appears from the following (Parsons, Shils, et al. 1951: 10n13): "A distinction between affect and cathexis is desirable for present purposes. Affect refers to a state of an organism - a state of euphoria or dysphoria or qualitative variants thereof. Cathexis refers to a state of an organism - a state of euphoria or dysphoria in relation to some object. Thus the term cathexis is broader in its reference than the term affect; it is affect plus object. It is object-oriented affect. It involves attaching affective significance to an object; although it involves attachment to one or more properties of the object, as used here it does not itself refer to a property of the object, but to a relation between actor and object. Furthermore, there is no connotation either of activity or passivity in the actor's relation to the object implied in the concept." On the specifically Innenwelt side, see Murray 1951: 453n. (The distinction Kluckhohn 1951: 395 attempts to draw between cathexis and valuation amounts to no more than the difference between cathexis within a generically animal Umwelt and a speciesspecifically human Lebenswelt.) 
the signs of which Augustine spoke, which they now proposed to call rather ${ }^{64}$ 'instrumental' signs.

"But by now the discussion was no longer exclusively in the hands of the scholastic realists. The key distinction this time came rather from the nominalists after Ockham; and they were thinking exclusively of particular things, alone, according to their doctrine, belonging to the order of ens reale, in contrast to every relation which is as such an ens rationis. ${ }^{65}$ Out of some two centuries of obscurity in which other issues held the center stage ${ }^{66}$ the Latin discussion of the 16th century took a turn in Iberia which was richly to vindicate Peirce's later thesis that an essential difference separated his Pragmaticism from the varieties springing up under his earlier label of Pragmatism, in that to the former scholastic realism is essential, while the latter remains compatible with nominalism.

"The decisive realization came cumulatively in the 16th and 17th centuries through the work of Soto (1529), Fonseca (1564), the Conimbricenses (1607), Araújo (1617), and finally Poinsot (1632), in whose writing the decisive realization approximates unmistakable clarity. ${ }^{67}$ This realization was twofold. One part ${ }^{68}$ lay in the insight that not relation as such, but relation as triadic, constituted the being of the sign, while the sensible element (or, in the case of the formal sign, the psychological element) that occupied the role of other-representation is what we call a 'sign' in the common, loose way of speaking. ${ }^{69}$ The other part ${ }^{70}$ lay in the insight that it is not anything about relation as suprasubjective that determines whether it belongs to the order of ens reale or ens rationis, but wholly and solely the circumstances of the relation. ${ }^{71}$ Whence one and the same relation, under one set of circumstances ens reale, by change of those circumstances alone could pass into an ens rationis without any detectable objective difference in the direct experience of the animal.

"Then came the virtual extinction of semiotic consciousness that we call modernity, a dark age that did not really end until Peirce returned to the late Latin writings and resumed the thread of their developing semiotic

${ }^{64}$ See the discussion of this terminology in the Four Ages (Deely 2001: 390n71).

${ }^{65}$ See Chapter 8 of the Four Ages (Deely 2001: esp. 385-393).

66 "The Thicket", in the Four Ages (Deely 2001), pp. 394-408).

67 The Four Ages, Chapters $9 \& 10$. In particular, see the Index entry SEMIOTIC CONSCIOUSNESS (Deely 2001: 988-89).

${ }^{68}$ Poinsot 1632: Treatise on Signs, Book I, Question 3 (that the relation of sign to signified and the relation of sign to power are one single relation, thus irreducibly triadic).

${ }^{69}$ See note 18 , p. 7 above.

${ }^{70}$ Poinsot 1632: Treatise on Signs, Book I, Question 2 (that the physical status of the sign to signified component of sign relations is determined by the context in which the sign functions).

${ }^{71}$ See "The Problem of the Nose of Wax" in the Four Ages (Deely 2001), Chapter 8, esp. $369-372$ text, and note 24 to p. 370 . 
consciousness, first by explicitly naming the three elements or terms grounding the triadic sign relation, and then by shifting the emphasis from being to action with the identification of semiosis. The foreground element of representation in the sign relation Peirce termed the representamen. ${ }^{72}$ This is what is loosely called a sign, but in reality is a sign-vehicle conveying what is signified to some individual or community, actual or prospective. The other represented or conveyed by the sign-vehicle Peirce traditionally termed the significate or object signified (in this two-word expression, to tell the truth, the first word is redundant). Whereas the prospective other to which representation is made (emphatically not necessarily a person, as Peirce was the first to emphasize ${ }^{73}$ and later semiotic analysis was to prove ${ }^{74}$ ) Peirce termed $^{75}$ the interpretant, 'the proper significate outcome' of the action of signs."

My colleague interrupted my historical excursus at this point.

"Do you really mean to call the period between Descartes and Peirce the semiotic dark ages?" he queried. "Isn't that a little strong?"

"Well", I half apologized, "the shoe fits. Nor do the semiotic dark ages simply end with Peirce, I am afraid. They extend into the dawn of our own century, though I am confident we are seeing their final hours. After all, a darkness precedes every full dawn."

"I saw an ad for a new book of yours comparing today's philosophical establishment with the judges of Galileo. That's not likely to get you job offers at the top", my colleague admonished.

"Yes", I sighed; "the ad drew on the Aviso prefacing my history of philosophy. ${ }^{76}$ It was calculated, well or ill, to sell the book to those disaffected from the philosophical side of modernity, its 'dark side', ${ }^{77}$ as distinguished from the glorious development of ideoscopic ${ }^{78}$ knowledge that we call science."

"Ideoscopic?"

"Knowledge that cannot be arrived at or verified without experimentation and, often, the help of mathematical formulae", I explained.

"As opposed to what? Common sense?"

${ }^{72}$ Latin derived, this term should be pronounced "rep-re-sen-tá-men", not "rep-resént-a-men", as the Anglophile Peirceans would have it.

${ }^{73}$ Peirce 1904.

${ }^{74}$ Krampen 1981; Deely 1987, 1989, 1993.

${ }^{75}$ Peirce c. 1907: CP 5.473.

76 "Aviso", pp. vii-viii of the Four Ages (Deely 2001).

${ }^{77}$ See "Synthesis and Successors: The Strange Case of Dr. Jekyll and Mr. Hyde", Chapter 13 in the Four Ages (Deely 2001: 540-589, esp. 565-572).

${ }^{78}$ Also spelled "idioscopic". See the Index entry in the Four Ages (Deely 2001: 910). 
"No", I explained further, "as opposed to coenoscopic ${ }^{79}$ knowledge, the systematic realization of consequences implied by the way we take 'reality' to be in those aspects wherein direct experimentation, and still less mathematization, isn't of much avail. In semiotics ${ }^{80}$ this distinction has been explained as the distinction between doctrina and scientia as the scholastics understood the point prior to the rise of science in the modern sense. Peirce himself ${ }^{81}$ characterized the distinction as 'cenoscopic' vs. 'idioscopic', borrowing these terms from Jeremy Bentham."

"More strange terminology. Why can't semioticians talk like normal people? And by the way, is Peirce's usage faithful to that of Bentham, and is Bentham actually the originator, the coiner, of these terms?"

"Normal is as normal does", I said with mild exasperation. "How can you develop new ideas without new words to convey them? Of course old words used in unfamiliar ways can also serve, but tend to mislead in any case. Surely you won't deny that new insights require new ways of speaking? Perhaps you've been an undergraduate teacher too long.

"Point taken", my colleague allowed ruefully. "But what about the reliability of Peirce's usage vis-à-vis Bentham's coinage of these terms, if he did coin them?"

"As to the exact relation of Peirce's appropriation to the sense of Bentham's original coinage", I said, "I can't help you there. I have never looked into Bentham directly. But I find the distinction in Peirce useful, even crucial, to understanding the postmodern development of semiotics."

"You said just now", my colleague said, returning at this point to my interrupted historical excursus, "that what I would call the 'common sense' notion of sign, a particular thing representing something other than itself, Peirce called technically a representamen, and that this is not the sign itself technically speaking but what you rather termed a 'sign-vehicle', functioning as such only because it is the foreground element in the three elements whose linkage or bonding makes up the sign technically or strictly speaking."

"Yes", I allowed, "you have followed me well. What makes something appear within sense-perception as a sign in the common or loose sense is not anything intrinsic to the physical subjectivity of the sensed object as a thing but rather the fact that the objectified thing in question stands in the position of representamen within a triadic relation constituting a sign in its proper being technically and strictly. So that physical structure before the building in your line of vision that tells you this is no longer Monaghan House is a sign

${ }^{79}$ Also spelled "cenoscopic". See the Index entry in the Four Ages (Deely 2001: $865)$.

${ }^{80}$ The discussion began with Sebeok 1976, and was picked up in Deely 1976 and 1978a (the former an essay review of Eco 1976, the latter an essay review of Sebeok 1976). The point became an Appendix in Deely 1982: 127-130, an encyclopedia entry in Sebeok et al. 1986: I, 214, and is hardly regarded as controversial any longer among those cognizant of the discussion, as Petrilli and Ponzio have remarked (2001: passim).

${ }^{81}$ Peirce c.1902: CP 5.424. 


\section{John Deely}

not strictly but loosely. Strictly it is the element of other-representation within a triadic relation having you with your semiotic web of experience and private semiosis as a partial interpretant, and this building here housing my office among other things as its signified object. Moreover, note that the physical structure of the particular thing appearing in your Umwelt as a sign may be subjected to ideoscopic analysis, but that that analysis will never reveal its sign-status as such. The recognition of signs as triadic relations in contrast to related things as subjective structures is a strictly coenoscopic achievement, although of course the semiosis of such things can well be developed ideoscopically by the social sciences, and philosophy will then be obliged to take such ideoscopic developments into account if it wishes to keep up with the reality of human experience as a whole."

"Now that is amazing." My colleague seemed delighted.

"What is amazing?"

"That I now see what you mean in saying that a sign is what every object presupposes. You mean that every object as an object depends upon a network of triadic relations, and that precisely these relations constitute the being of a sign strictly speaking. Hence without objects there would be isolated sensory stimuli, but no cathexis ${ }^{82}$ no cognition, establishing a world of objects wherein some appear desirable $(+)$, others undesirable (-), with still others as matters of indifference (0)."

"That is only part of it."

"Part of it?"

"Yes. Every sign acting as such gives rise to further signs. Semiosis is an open process, open to the world of things on the side of physical interactions and open to the future on the side of objects. Thus you need to consider further that sign-vehicles or representamens, objects signified or significates, and interpretants can change places within semiosis. What is one time an object becomes another time primarily sign-vehicle, what is one time interpretant becomes another time object signified, and what is one time object signified becomes another time interpretant, and so on, in an unending spiral of semiosis, the very process through which, as Peirce again put it, 'symbols grow'."

"So signs have a kind of life within experience, indeed provide experience almost with its 'soul' in the Aristotelian sense of an internal principle of growth and development! One man's object is another man's sign, and an object one time can be an interpretant the next."

"Now you're getting the idea. Be careful. Next thing you know you'll claim to be a semiotician."

"So signs strictly speaking are invisible."

${ }^{82}$ In connection with our earlier note on this term (note 63, p. 28 above), we may add here that the importance of introducing this term into semiotics is to provide a marker for Peirce's seminal idea (c.1907: 00035-36) that, within the life of animals, "every sign whatever that functions as such must have an emotional interpretant". 
"Yes, and inaudible and intactile, for that matter. By contrast, a sign loosely speaking, an element occupying the position of representamen in a renvoi relation vis-à-vis significate and interpretant, can indeed be seen and pointed to or heard. A great thinker of the $20^{\text {th }}$ century once remarked, ${ }^{83}$ perhaps without realizing the full depth of what he was saying, that animals other than humans make use of signs, but those animals do not know that there are signs. The vehicles of signs can normally be perceived (as long as they are 'instrumental' rather than 'formal') and can become rather interpretants or signifieds; but the signs themselves are relations, like all relations irreducibly suprasubjective, but unique too in being irreducibly triadic. Signs, in short, strictly speaking can be understood but not perceived; while 'signs' loosely speaking can be both perceived and understood, but when they are fully understood it is seen that what we call signs loosely are strictly representamens, the foreground element in a given triadic relation through which alone some object is represented to some mind, actually or only prospectively."

"What do you mean 'prospectively'?"

I sighed. "You bring up another story for which the world is not yet prepared."

"I do?" My colleague looked worried, perhaps seeing lunch disappearing in a cloud of verbiage, and having had enough of the case of the giant rat of Sumatra on the table between us, still staring beady-eyed his way.

"Indeed you do. Remember a little while ago when the subject of evolution came up?"

"Indeed I do, and I can tell you that I am happy you didn't insist on going into it."

"Nor will I now, except to say this. Up to the present evolution has been understood mainly as a vis a tergo, building up from below through individual interactions structures increasingly complex and far-flung. ${ }^{84} \mathrm{I}$ have a suspicion that this picture is incomplete in just the way that requires semiosis. For the action of signs is distinctive as compared with the action of things in that the action of things takes place only among actual physical existents, whereas semiosis requires at any given time only that two out of the three related elements actually exist. In physical interactions always the past shapes the future, but in semiosic interactions there is an influence of the future upon the present and even upon the past as bearing on the present, so to speak. My suspicion is that wherever you have evidence of such an influence you have semiosis, an action of signs. And since we can see from the semiosis

${ }^{83}$ Maritain 1957: 55: "So far we have spoken of genuine language. Let us point out that the word 'language', when referring to animals, is equivocal. Animals possess a variety of means of communication but no genuine language. I have observed that animals use signs. But, as I also pointed out, no animal knows the relation of signification or uses signs as involving and manifesting an awareness of this relation." See this important article on the point passim.

${ }^{84}$ Dennett 1995. 
of animal life that the very possibility of semiosis in general is rooted in the indifference of relation to its subjective ground on the one side and to the physical unreality of its object on the other side, ${ }^{85}$ I venture to guess that a physiosemiosis, prior to and surrounding even the biosemiosis of which Sebeok speaks, ${ }^{86}$ with its phytosemiosis, zoösemiosis, and anthroposemiosis as parts, will prove to be at the heart of what has heretofore been called, faut de mieux, evolution."

"Sebeok?" my colleague queried. "This is the second time you have spoken his name in this discussion. Who is he? And is he important for semiotics?"

I could not but chuckle at the relativity of fame. "Of the three most important figures in the later twentieth century development of semiotics", I averred, "Sebeok is the second most famous and the first in importance. He is to semiotics today what Mersenne was and more to philosophy in the time of Descartes. I am astonished you have not yourself heard of him or read something of his work, if not in semiotics then at least in linguistics, anthropology, or folklore."

"Does he accept your notion of sign as presupposed to object?"

"Well, I am reasonably confident that he would, although I have never put the question to him in just that way. After all, it is a formula I have stumbled upon only recently, ${ }^{87}$ and have not had a chance for extended discussions with Sebeok in quite some time, although I had hoped to arrange a visit this past summer. My main disagreement, if it can be called that, with Sebeok concerns not so much the question of objects in the sense we have discussed but concerns rather the bearing of semiosis upon the very idea of things in the universe. Over the last decade of the twentieth century and into this one, ${ }^{88}$ Sebeok has envisioned a 'cosmos before semiosis'. In this way of thinking, the idea of 'nonbiological atomic interactions' as well as 'those of inorganic molecules' prior to the origin of life being 'semiosic' appears as 'surely metaphorical', as Sebeok puts it." ${ }^{~} 9$

My colleague frowned. "Surely this Sebeok is right. Inorganic substances do not interpret signs, or involve themselves in renvoi!"

It was my turn to frown. "I am not so sure. I think that here Sebeok has been uncharacteristically hasty in his dismissal of a semiosis virtually active in the world of things. The whole question of the 'anthropic principle' is one that implies semiosis from the very beginning of the universe."

${ }^{85}$ Poinsot 1632: Second Preamble, Article 2, esp. 95/18-96/36; and Book I, Question 1, esp. 117/28-118/18.

${ }^{86}$ Sebeok 2001a. But see also Sebeok and Umiker-Sebeok 1992, Hoffmeyer and Emmeche 1999, and Hoffmeyer 1996.

87 "A New Definition of Signum" in the Four Ages (Deely 2001: 434-435). But cf. Deely 1996.

${ }_{88}$ "The Evolution of Semiosis", in Sebeok 1991: 83-96; reprinted in Sebeok 2001: 17-30.

${ }^{89}$ Sebeok 1991: 84, 2001: 18. 
"An action of signs in the universe prior even to the advent of life? If that's not to indulge in metaphor I don't know what is", my colleague ventured.

"There is another alternative", I said, "a third way between metaphor and organic semiosis, a way suggested, in fact, by the father of systematic semiotics, if we may so speak of the first thinker theoretically to unify the notion of sign under the rubric of triadic relation or, as we are now inclined to say, 'renvoi'. According to Poinsot, ${ }^{90}$ it suffices to be a sign virtually in order to actually signify. By this formula, even in the prima facie dyadic interactions of things relations are born sufficient to constitute a semiosis at work in the inorganic no less than organic layers of nature, and prior even to the advent of the organic layers - indeed anticipatory of that advent. This is an argument I began in $1990^{91}$ and have continued to develop since under the rubric 'physiosemiosis'." 92

"Semiosis, signs at work in physical nature as such? That sounds crazy. No wonder some people regard semiotics as an imperialistic development!"

"Well, it is only a guess. But others besides me, ${ }^{93}$ to say nothing of Peirce before me ${ }^{94}$ have made analogous suggestions. Time will tell!"

"A discussion for another time. I hate to end a good discussion on a note of shibboleth, but let us go to eat."

I nodded in agreement and started to rise, when my friend raised his hand to stay me.

"One last question, to be answered in the briefest of terms."

"Go ahead."

"Are you saying that to know signs in the strict sense, to thematize sign, as it were, requires a species-specifically human Innenwelt?"

"Just so. For the imperceptible distinction between subjectivity and suprasubjectivity, between relations and related things, is at the heart of linguistic communication so far as it does not reduce to perceptible elements. ${ }^{95}$ And it is the point of departure for anthroposemiosis in its difference from all zoösemiosis. ${ }^{96}$ All animals are semiosic beings, but only

${ }^{90}$ Poinsot 1632: Tractatus de Signis, Book I, Question 1, "Resolution of CounterArguments", esp. 126/3-4, and 126/ 9-22.

${ }^{91}$ Deely, Basics of Semiotics, Chapter 5.

${ }^{92}$ On the term physiosemiois, then, see Deely 1990, 1991, 1993, 1998, 1999, and $2001 b$.

${ }^{93}$ E.g., Prodi 1977; Koch 1987; Kruse 1994; Corrington 2001. See the umbrella symposium convened by Nöth 2001 to open the new century.

${ }^{94}$ Besides my own analysis of what I termed "Peirce's Grand Vision" (Deely 1989), Nöth 2001: 16, observes that "renowned Peircean scholars, such as Helmut Pape (1989), Klaus Oehler (1993), and Lucia Santaella-Braga (1994, 1996, 1999), affirm that the origins of semiosis, according to Peirce, begin before life."

${ }^{95}$ Deely 1980, 2001a.

${ }^{96}$ Such was the argument of Deely 1994, sharply focused in Deely 2001a. 
human beings can become semiotic animals - animals, that is to say, that both use signs and know that there are signs."

"I like that. 'The semeiotic animal': a new definition for humanity as the postmodern age opens. Let us say goodbye to the res cogitans, even as Descartes said goodbye to the animal rationale; and, like good semiotic animals, let us set out in search of sign-vehicles which can lead us to objectified things pleasant to eat. How about the Black Lab?" Now my colleague rose.

I rose with him and together we set out in search of food. We had not far to go, for the Black Labrador is a rather good restaurant not two full blocks from the place of our discussion where my colleague's initial incredulity gave way to the conviction that, while there is yet more to be said, yet at least this much is certain even now: the sign is what every object presupposes.

Since what is last in discovery becomes first in exposition, the last discovery of the moderns in the person of Peirce has become the first theme postmodern philosophy and intellectual culture must come to terms with (since it defines them). It is not a bad discovery, even if compared to the late Latins it was only a rediscovery. Small wonder that, all thought being in signs, the objective universe is perfused with them. It remains to see if even the physical universe may not as giving rise to us consist exclusively of signs. But after lunch ...

\section{References}

Anshen, Ruth Nanda (ed.) 1957. Language: An Enquiry into Its Meaning and Function (New York: Harper \& Bros.).

Bentham, Jeremy 1816. Chrestomathia: Being a Collection of Papers, Explanatory of the Design of an Institution Proposed to be Set on Foot Under the Name of the Chrestomathic Day School, or Chrestomathic School, for the Extension of the New System of Instruction to the Higher Branches of Learning, For the Use of the Middling and Higher Ranks in Life, in The Works of Jeremy Bentham, ed. John Bowring (Edinburgh, 1838-1843; reproduced 1962 by Russell \& Russell, Inc., New York), Vol. 8, pp. 1-191, esp. Appendix No. IV, the "Essay on Nomenclature and Classification", 63-128.

Beuchot, Mauricio; Deely, John 1995. Common sources for the semiotic of Charles Peirce and John Poinsot. Review of Metaphysics 48(3): 539-566.

Brentano, Franz 1874. Psychologie von Empirischen Standpunkt, trans. Linda McAlister, A. Rancurello, and D. B. Terrell as Psychology from an Empirical Standpoint (New York: Humanities Press, 1963).

Burks, Arthur W. 1958. Bibliography of the Works of Charles Sanders Peirce. In: The Collected Papers of Charles Sanders Peirce, Volume VIII, ed. Arthur W. Burks. Cambridge: Harvard University Press, 249-330. 
Conimbricenses 1607. "De Signis", being Chapter 1 of their commentary on Aristotle's De Interpretatione, in: Commentarii Collegii Conimbricensis et Societatis Jesu. In Universam Dialecticam Aristotelis Stagiritae. Secunda Pars (Lyons: Sumptibus Horatii Cardon, 1607), 4-67. ${ }^{97}$

Corrington, Robert S. 2000. A Semiotic Theory of Theology and Philosophy. Cambridge: Cambridge University Press.

Deely, John 1971. The myth as integral objectivity. ACPA Proceedings 45: 61-76.

- 1975. Reference to the non-existent. The Thomist 39(2): 253-308.

- 1976. The doctrine of signs: Taking form at last. Semiotica 18(2): 171-193 (essay review of Eco 1976).

- 1978. Semiotic and the controversy over mental events. ACPA Proceedings 52: $16-27$.

- 1978a. What's in a name? Semiotica 22(1/2): 151-181 (essay review of Sebeok 1976).

- 1980. The nonverbal inlay in linguistic communication. In: Rauch, Irmengard; Carr, Gerald F. (eds.), The Signifying Animal. Bloomington: Indiana University Press, 201-217.

- 1982. Introducing Semiotic: Its History and Doctrine. Bloomington: Indiana University Press.

- 1986. A context for narrative universals: Semiology as a Pars Semeiotica. The American Journal of Semiotics 4(3/4): 53-68.

- 1986a. Idolum: Archeology and ontology of the iconic sign. In: Bouissac, Paul; Herzfeld, Michael; Posner, Roland (eds.), Iconicity: Essays on the Nature of Culture, Festschrift volume in honor of Thomas A. Sebeok. Tübingen: Stauffenburg Verlag, 29-49.

- 1987. On the notion of phytosemiotics. In: Deely, John; Evans, Jonathan (eds.), Semiotics 1982. Lanham: University Press of America, 541-554. (Reprinted with minor revision in Deely et al. 1986: 96-103.)

- 1989. "The Grand Vision", presented on September 8 at the September 5-10 Charles Sanders Peirce Sesquicentennial International Congress at Harvard University, in: Colapietro and Olshewsky (eds.) 1996: 45-67.

- 1990. Basics of Semiotics (Bloomington: Indiana University Press).

- 1991. Semiotics and Biosemiotics: Are Sign-Science and Life-Science Coextensive? In: Sebeok and Umiker-Sebeok 1992: 45-75. Since revised as Chapter 6 "How Do Signs Work?" in: Deely 1994b: 151-182.

- 1993. "How Does Semiosis Effect Renvoi?", the Thomas A. Sebeok Fellowship Inaugural Lecture delivered at the 18th Annual Meeting of the Semiotic Society of America, October 22, 1993, St. Louis, MO; published in The American Journal of Semiotics 11.1/2 (1994): 11-61; text available also as Ch. 8 of Deely 1994b: 201-244.

- 1994. The Human Use of Signs; or Elements of Anthroposemiosis. Lanham: Rowman \& Littlefield.

${ }^{97}$ An earlier edition minus the Greek text of Aristotle was published at Coimbra itself in 1606. This work has just been translated into English and published in a bilingual critical edition: see under Doyle (ed.) 2001. 
- 1994b. New Beginnings: Early Modern Philosophy and Postmodern Thought. Toronto: University of Toronto Press.

- 1995. Why investigate the common sources of Charles Peirce and John Poinsot? In: Spinks, C. W.; Deely, John (eds.), Semiotics 1994. New York: Peter Lang Publishing, 34-50.

- 1996. A New Beginning for the Sciences. In: Perron, Paul; Danesi, Marcel; Colilli, Paul; Wattanabee, John (eds.), Semiotics as a Bridge between the Humanities and the Sciences (proceedings of the 2-6 November 1995 Symposium organized at Victoria College by Prof. Danesi; Ottawa: Legas Press, 2000), 95-108.

- 1998. How is the universe perfused with signs? In: Spinks, C. W.; Deely, John (eds.), Semiotics 1997. New York: Peter Lang, 389-394.

- 1999. Physiosemiosis and semiotics. In: Spinks, C. W.; Deely, John (eds.), Semiotics 1998. New York: Peter Lang, 191-197.

- 2000. The Latin Foundations for Semiotic Consciousness: Augustine $\left(5^{\text {th }}\right.$ century AD) to Poinsot $\left(17^{\text {th }}\right.$ century $\left.\mathrm{AD}\right)$. Recherches Semiotiques/Semiotic Inquiry 20.1-2-3: 11-32.

- 2001. Four Ages of Understanding. The first postmodern survey of philosophy from ancient times to the turn of the twenty-first century. Toronto: University of Toronto Press.

- 2001a. What Distinguishes Human Understanding?, an essay on the intersemiosis of perception and understanding (South Bend: St. Augustine's Press).

- 2001b. Physiosemiosis in the semiotic spiral: A play of musement. Sign Systems Studies 29(1): 27-47.

- 2001c. A new determination of the Middle Ages. In: Doyle (ed.) 2001, [Foreword].

Deely, John N.; Williams, Brooke; Kruse, Felicia E. (eds.) 1986. Frontiers in Semiotics. Bloomington: Indiana University Press. [Preface titled "Pars Pro Toto", viii-xvii; "Description of Contributions", xviii-xxii.]

Dennett, Daniel 1995. Darwin's Dangerous Idea. New York: Simon and Schuster. Doyle, John P. (ed. and trans.) 2001. The Jesuits of Coimbra (Conimbricenses) on Signs. Milwaukee: Marquette University Press. (Bilingual critical edition of Conimbricenses 1607, q.v.)

Eco, Umberto 1976. A Theory of Semiotics. (Trans. David Osmond-Smith.) Bloomington: Indiana University Press.

- 1987. The influence of Roman Jakobson on the development of semiotics. In: Krampen, Martin; Oehler, Klaus; Posner, Roland; Sebeok, Thomas A., Uexküll, Thure von (eds.), Classics of Semiotics. New York: Plenum Press, 109127.

Eco, Umberto; Deely, John 1983, May 30-June 24. "Historiographical Foundations of Semiotics", course taught at ISISSS'83 (Indiana University, Bloomington campus). This course exists in a series of twenty-six untranscribed cassettes created by students in the course.

Eco, Umberto; Lambertini, Roberto; Marmo, Costantino; Tabarroni, Andrea 1986. Latratus Canis or: The Dog's Barking. In: Deely, Williams, and Kruse 1986: 63-73; see the editorial note on the background of this text, ibid. p. xix. 
Fonseca, Petrus ("Pedro da") 1564. Institutionum dialecticarum libri octo (Coimbra: Apud haeredes Joannis Blauij). The most important edition of this work thus far is the bilingual presentation comparable to Poinsot 1632 (q.v.) of Joaquim Ferreira Gomes, Instituiães Dialecticas (Institutionum dialecticarum libri octo), 2 vols. (Instituto de Estudos Filosoficos da Universidad de Coimbra, 1964).

Grote, George 1872. Aristotle, posthumous ed. by Alexander Bain and G. Croom Robinson (London: J. Murray), 2 vols.

Hardwick, Charles S., editor, with the assistance of James Cook 1977. Semiotics and Significs: The Correspondence between Charles S. Peirce and Victoria Lady Welby. Bloomington: Indiana University Press.

Heidegger, Martin 1963 [1927]. Sein und Zeit, originally published in the Jahrbuch für Phänomenologie und phänomenologische Forschung, ed. E. Husserl. Page references in the present work are to the 10th edition (Tübingen: Niemeyer, 1963).

Hoffmeyer, Jesper 1996. Signs of Meaning in the Universe. Bloomington: Indiana University Press.

Hoffmeyer, Jesper; Emmeche, Claus (eds.) 1999. Biosemiotics, Special Issue of Semiotica 127.

Husserl, Edmund 1929 [1960]. Cartesian Meditations: An Introduction to Phenomenology, trans. by Dorion Cairns. The Hague: Martinus Nijhoff. (Of a work that appeared in Husserl's lifetime only in French.)

- 1936 [1954]. The crisis of European sciences and transcendental phenomenology. An introduction to phenomenological philosophy, trans. with an Introduction by David Carr (Evanston: Northwestern University Press, 1970) of Die Krisis der europäischen Wissenschaften und die transzendentale Phänomenologie; eine Einleitung in die phänomenologische Philosophie, posthumously edited by Walter Biemel and published in German 1954.

Jakobson, Roman 1979 [1974]. Coup d'oeil sur le devéloppement de la sémiotique. In: Chatman, Seymour; Eco, Umberto; Klinkenberg, Jean-Marie (eds.), Panorama sémiotique/A Semiotic Landscape, Proceedings of the First Congress of the International Association for Semiotic Studies, Milan, June 1974. The Hague: Mouton, 3-18. ${ }^{98}$

Kluckhohn, Clyde 1951. Values and value-orientation in the theory of action. In: Parsons, Talcott; Shils, Edward (eds.) 1951: 388-433.

Koch, Walter A. 1987. A plea for evolutionary cultural semiotics. In: A Plea for Cultural Semiotics. Bochum: Brockmeyer, 53-131.

${ }^{98}$ Also published separately under the same title by the Research Center for Language and Semiotic Studies as a small monograph (= Studies in Semiotics 3; Bloomington: Indiana University Publications, 1975); and in an English trans. by Patricia Baudoin titled "A Glance at the Development of Semiotics", in: The Framework of Language (Ann Arbor: Michigan Studies in the Humanities, Horace R. Rackham School of Graduate Studies, 1980), 1-30. 
Kramer, Heinrich ("Henricus Institutoris"); Sprenger, Jacob 1951 [1486]. Malleus Maleficarum ("Hammer of Witches", trans. with Introduction, Bibliography, and Notes by Montague Summers). London: Pushkin Press. ${ }^{99}$.

Krampen, Martin 1981. Phytosemiotics. Semiotica 36(3/4): 187-209; substantially reprinted in Deely, Williams and Kruse 1986.

Kruse, Felicia E. 1994. Is cosmic evolution semiosis? In: Moore, Edward C.; Robin, Richard S. (eds.), From Time and Chance to Consciousness: Studies in the Metaphysics of Charles Peirce. Oxford: Berg, 87-98.

Kull, Kalevi (ed.) 2001. Jakob von Uexküll: A Paradigm for Biology and Semiotics, a Special Issue of Semiotica 134(1/4).

Manetti, Giovanni 1987. Le teorie del segno nell'antichità classica. Milan: Bompiani. (Trans. by Christine Richardson as Theories of the Sign in Classical Antiquity. Bloomington: Indiana University Press, 1993.)

Maritain, Jacques 1957. "Language and the Theory of Sign", originally published in English in: Anshen (ed.) 1957: 86-101, is reprinted, with the addition of a full technical apparatus explicitly connecting the essay to Maritain's work on semiotic begun in 1937 and to the text of Poinsot 1632 on which Maritain centrally drew, in: Deely, Williams and Kruse (eds.) 1986: 51-62. Page references in this dialogue are based on the 1986 reprint as the most definitve English version.

Markus, R. A. 1972. St. Augustine on signs. In: Markus, R.A. (ed.), Augustine. A Collection of Critical Essays. Garden City, NY: Doubleday \& Co., 61-91.

McInerny, Ralph 2001. Thomas Reid and the signs of the times, a subsection of Lecture IV of McInerny's 1999-2000 Gifford Lectures, Characters in Search of Their Author (Notre Dame: University of Notre Dame Press), 52-56.

Murray, Henry A. 1951. Toward a classification of interaction. In: Parsons and Shils (eds.) 1951: 434-464.

Nöth, Winfried 2001. Protosemiotics and physicosemiosis. In: Nöth (organizer) 2001: 13-26.

Nöth, Winfried (organizer) 2001. German-Italian Colloquium "The Semiotic Threshold from Nature to Culture", Kassell, Germany, 16-17 February at the Center for Cultural Studies, University of Kassel; papers published together with the Imatra 2000 Ecosemiotics colloquium in The Semiotics of Nature, a

${ }^{99}$ This work appeared with a singular Preface, to wit, the Papal Bull Summis desiderantes affectibus of 9 December 1484 (the very first year of the Pontificate of Innocent VIII), a document of highest authority in which Kramer and Sprenger are named specifically as the already-delegated Inquisitors in the matter of witcheraft with renewed emphasis: "By our supreme authority we grant them anew full and complete faculties" throughout the German territories, including, as circumstances warrant, "the help of the secular arm". To this Preface was added an Official Letter of Approbation of the work from the Faculty of Theology of the University of Cologne, dated 19 May 1487.

Summers, in his Introduction (p. xiv) notes that, for nearly three centuries after its appearance, "the Malleus lay on the bench of every judge, on the desk of every magistrate. It was the ultimate, irrefutable, unarguable authority. It was implicitly accepted not only by Catholic but by Protestant legislature." 


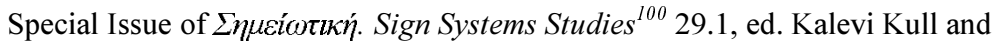
Winfried Nöth.

Oehler, Klaus 1993. Charles Sanders Peirce. München: Beck.

Pape, Helmut 1989. Erfahrung und Wirklichkeit als Zeichenprozess. Frankfurt am Main: Surkamp.

Parsons, Talcott; Shils, Edward (eds.) 1951. Toward a General Theory of Action. Cambridge: Harvard University Press.

Parsons, Talcott; Shils, Edward; Allport, Gordon W.; Kluckhohn, Clyde; Murray, Henry A.; Sears, Robert R.; Sheldon, Richard C.; Stouffer, Samuel A.; Toulmin, Edward C. 1951. Some fundamental categories of the theory of action: A general statement. In: Parsons, Shils (eds.) 1951: 3-29.

Parsons, Talcott; Shils, Edward, with the assistance of Olds, James 1951. Categories of the orientation and organization of action. In: Parsons and Shils (eds.) 1951: 53-109.

Peirce, Charles Sanders (ed.) 1883. Studies in Logic by members of the Johns Hopkins University (Boston: Little, Brown, and Co.), 1-11. Facsimile reprint with an Introduction essay by Max H. Fisch and a Preface by Achim Eschbach as Volume 1 in the series "Foundations in Semiotics" under the general editorship of Eschbach (Amsterdam/Philadelphia: John Benjamins Publishing Co., 1983).

- c.1897. A fragment on semiotics, partially printed in CP $2.227-229,2.244 \mathrm{n} 1$.

- c.1902. "Minute Logic", draft for a book complete consecutively only to Chapter 4. Published in CP in extracts scattered over six of the eight volumes, including $1.203-283,1.575-584 ; 2.1-202 ; 4.227-323$, 6.349-352; 7.279, 7.374n10, 7.362-387 except 381n19. (For fuller detail, see Burks 293-294.)

- 1904. Letter of 12 October from Peirce to Lady Welby. In: Hardwick, Charles S. (ed.) 1977: 22-36.

- 1905. What Pragmatism Is. The Monist 15 (April): 161-181; reprinted in CP 5.411-437, with 5.414-5.435 being editorially headed "Pragmaticism" in CP.

- 1905a. Issues of Pragmaticism., The Monist 15 (October): 481-499; reprinted in CP 5.438-463, except 448n1, which is from 1906 [see Burks, entry for 1905(d), p. 298] (Burks p. 297). Also reprinted in The Essential Peirce, ed. Nathan Houser et al. (Bloomington: Indiana University Press; hereafter EP), 2.346-359.

— c.1905. Unsigned letter addressed to Signor Calderoni, in CP 8.205-213.

- 1907. "Pragmatism", Reading 28 in EP 2.398-433.

— c.1907. Ms. 318 in Robin 1967: 36-7, numbered ISP 00002-00350. ${ }^{101}$

100 This journal, founded by Juri Lotman in 1964, is the oldest contemporary journal of semiotics, and, interestingly, appeared in its first three issues [really 2-4, because the first issue, Lotman's "Lekcii po strukturalnoj poetike" came out without

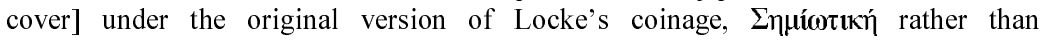
$\Sigma \eta \mu \varepsilon i ́ \omega \tau$ เ

${ }^{101}$ One of the most important of Peirce's literary remains, this many-layered ms. has never been published in full. Where I have drawn on unpublished sections I have used a photocopy bearing the sheet numbers stamped by the Texas Tech Institute for Studies in Pragmaticism (hence: ISP nos.) on the electroprint copy Ketner with associates had made from microfilm, and then checked against the original in the 
Petrilli, Susan; Ponzio, Augusto 2001. Thomas Sebeok and the Signs of Life. Cambridge: Icon Books.

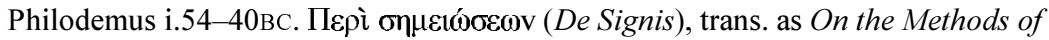
Inference in the ed. of Phillip Howard De Lacy and Estelle Allen De Lacy, rev. with the collaboration of Marcello Gigante, Francesco Longo Auricchio, and Adele Tepedino Guerra. Naples: Bibliopolis, 1978, Greek text pp. 27-87, English 91-131.

Poinsot, Joannes 1632. Tractatus de Signis, subtitled The Semiotic of John Poinsot, extracted from the Artis Logicae Prima et Secunda Pars of 16311632 (Alcalà, Spain) and arranged in bilingual format by John Deely in consultation with Ralph A. Powell (First Edition; Berkeley: University of California Press, 1985). ${ }^{102}$

Prodi, Giorgio 1977. Le basi materiali della significazione. Milano: Bompiani.

Rauch, Irmengard 1999. Semiotic Insights. Toronto: University of Toronto Press.

Reid, Thomas 1969 [1785]. Essays on the Intellectual Powers of Man. (Baruch Brophy, ed.) Boston: MIT Press.

Santaella-Braga, Lucia 1994. Peirce's broad concept of mind. European Journal for Semiotic Studies 6: 399-411.

- 1996. Semiosphere: The Growth of Signs. Semiotica 109: 173-186.

- 1999. A New Causality for Understanding of the Living. Semiotica 127: 497518.

Sebeok, Thomas A. 1976. Contributions to the Doctrine of Signs (jointly published originally by Indiana University, Bloomington: RCLSS Publications, and The Peter De Ridder Press, Lisse; reprinted with an extended Preface by Brooke Williams, "Challenging Signs at the Crossroads", evaluating the book in light of major reviews: Lanham: University Press of America).

- 1984, June 3. "The Evolution of Communication and the Origin of Language", lecture in the June 1-3 ISISSS " 84 Colloquium on "Phylogeny and Ontogeny of Communication Systems". Published under the title "Communication, Language, and Speech. Evolutionary Considerations", in: Sebeok 1986: $10-16$.

Harvard archives. Further subdivisions and rearrangements have been made since. Originally an untitled letter-article to the editor of The Nation, this ms. has several partial draft endings signed "Charles Santiago Peirce", but no single, consecutive, complete draft as a whole. CP 5.464-496, under a title supplied by the editors of the volume, "A Survey of Pragmaticism" (cf. Burks p. 299) is from this ms. 318. NEM III.1: 481-494 presents a small segment under the title "From Pragmatism". EP 2.398433, under the title "Pragmatism" (the 1907 entry immediately above), is the most complete, though still partial, presentation of this document.

${ }^{102}$ Pages are set in matching columns of English and Latin, with intercolumnar numbers every fifth line. (Thus, references to the volume are by page number, followed by a slash and the appropriate line number of the specific section of text referred to - e.g., 287/3-26.) This work is also available as a text database, standalone on floppy disk or combined with an Aquinas database, as an Intelex Electronic Edition (Charlottesville, VA: Intelex Corp., 1992). 
- 1984a. "Vital Signs", Presidential Address delivered to the Ninth Annual Meeting of the Semiotic Society of America on October 12 on the Bloomington campus of Indiana University; published in The American Journal of Semiotics 3.3 (1985): 1-27.

- 1984b. "Symptom", Chapter 10 of New Directions in Linguistics and Semiotics, ed. James E. Copeland (Houston: Rice University Studies), 212230.

- 1986. I Think I Am A Verb. More Contributions to the Doctrine of Signs. New York: Plenum Press.

- 1991. A Sign Is Just a Sign. Bloomington: Indiana University Press.

- 2001. Global Semiotics. Bloomington: Indiana University Press.

- 2001a. Biosemiotics: Its Roots, Proliferation, and Prospects. In: Kull (ed.) 2001: 61-78.

Sebeok, Thomas A. (ed.) 1977. A Perfusion of Signs. Bloomington: Indiana University Press.

Sebeok, Thomas A. (general ed.); Bouissac, Paul; Eco, Umberto; Pelc, Jerzy; Posner, Roland; Rey, Alain; Shukman, Ann (eds.) 1986. Encyclopedic Dictionary of Semiotics (Berlin: Mouton de Gruyter), in 3 vols.

Sebeok, Thomas A.; Umiker-Sebeok, Jean (eds.) 1992. Biosemiotics. The Semiotic Web 1991. Berlin: Mouton de Gruyter.

Soto, Dominicus ("Domingo de") 1529, 1554. Summulae (1st ed., Burgos; 2nd ed., Salamanca; 3rd rev. ed., Salamanca; Facsimile of 3rd ed., Hildesheim, NY: Georg Olms Verlag).

Spiegelberg, Herbert 1965. The Phenomenological Movement. 2 volumes. (2nd ed., rev.) The Hague: Martinus Nijhoff. 